\title{
Effects of glucose-insulin infusion during major oral and maxillofacial surgery on postoperative complications and outcomes
}

\author{
Akina Tohya, Atsushi Kohjitani', Sachi Ohno, Kaoru Yamashita, Yozo Manabe and Mitsutaka Sugimura
}

\begin{abstract}
Background: Secretion of hormones, which antagonize the action of insulin, is facilitated in response to surgery, and acute resistance to the action of insulin develops. Our aim is to elucidate the effects of intraoperative glycemic control by glucose-insulin (Gl) infusion on postoperative complications and outcomes in major oral and maxillofacial surgery.

Findings: Thirty patients aged $\geq 60$ years undergoing a radical operation of oral malignant tumors with tissue reconstruction ( $\geq 8 \mathrm{~h}$ ) were analyzed. In the Gl group, regular insulin was continuously applied with glucose-added acetate Ringer's solution (5-10 g glucose per $500 \mathrm{~mL}$ ). Blood glucose was adjusted within the target concentration of $80-120 \mathrm{mg} / \mathrm{dL}$. In the control group, combination of acetate Ringer's solution containing 1\% (W/V) glucose and lactate Ringer's solution, which contains no glucose, was employed. Perioperative clinical parameters, incidence of hypoalbuminemia, and postoperative complications, i.e., surgical site infection, necrosis of a reconstructed flap, bacteremia, hypotension, or pneumonia, were compared. Both serum total protein and albumin concentrations (postoperative day 1 [Day1]) were higher in the Gl group. The mean infusion rate of glucose during surgery $(\mathrm{mg} / \mathrm{kg} / \mathrm{h})$ was independently associated with the decrease in both serum total protein and albumin concentrations from the control to Day1. No difference was found between the groups in the incidence of postoperative complications and the days required until discharge, except less incidence of hypoalbuminemia in the Gl group.
\end{abstract}

Conclusions: Application of additional glucose during major oral and maxillofacial surgery preserved serum albumin concentration. However, it did not lead to less postoperative complications and less days until discharge.

Keywords: Surgical diabetes, Inflammation, Hypoalbuminemia, Postoperative complication

\section{Introduction}

The neuroendocrine system facilitates the secretion of adrenaline, growth hormone, cortisol, and adrenocorticotropic hormone $(\mathrm{ACTH})$ in response to surgical stimulation, all of which antagonize the action of insulin. These counter-regulatory hormones augment gluconeogenesis in the liver, inhibit glucose uptake into cells, and interfere with insulin secretion from pancreatic $\beta$-cells, which leads to a state called "surgical diabetes" [1]. Furthermore, acute resistance to the action of insulin also develops during surgery $[2,3]$, especially in skeletal and

\footnotetext{
* Correspondence: atsushik@dent.kagoshima-u.ac.jp

Department of Dental Anesthesiology, Field of Oral and Maxillofacial Rehabilitation, Graduate School of Medical and Dental Sciences, Kagoshima University, 8-35-1 Sakuragaoka, Kagoshima 890-8544, Japan
}

cardiac muscle, adipose tissue, and the liver, where glucose uptake is regulated by glucose transporters [4].

Hyperglycemia triggers and amplifies a cascade of inflammatory responses. Hyperglycemia facilitates production of superoxide anions through activation of nicotinamide adenine dinucleotide phosphate (NADPH) oxidase $[5,6]$. Superoxide anions in turn trigger production of inflammatory cytokines, such as interleukin (IL)-1 $\beta$, IL-6, or tumor necrosis factor (TNF)- $\alpha$ [7], which augment both inflammatory responses and insulin resistance. Meanwhile, insulin exhibits anti-inflammatory actions by reducing production of inflammatory cytokines and reactive oxygen species [8].

Recently, control of blood glucose during the perioperative period has been emphasized because high blood glucose delays normal healing of surgical wounds 
and increases the risk of infection. Evidences revealed that tight glycemic control reduced morbidity and mortality of critically ill patients [9] and decreased infection rate and improved survival of coronary bypass graft surgery $[10,11]$. Furthermore, the anti-inflammatory effect of intensive insulin therapy during cardiac surgery has been demonstrated [12].

In the current study, we investigated the effects of intraoperative glycemic control by glucose-insulin (GI) infusion on postoperative complications and outcomes in elderly patients undergoing major oral and maxillofacial surgeries, which require $8 \mathrm{~h}$ or longer.

\section{Methods}

Thirty-nine patients diagnosed with oral malignant tumors who were aged $\geq 60$ years and scheduled for radical operation with tissue reconstruction (scheduled time required $\geq 8$ h) from February 2013 to May 2016 were enrolled following approval of the Clinical Ethical Committee of Kagoshima University Hospital. The study was further registered with the UMIN Clinical Trials Registry (UMIN-CTR), UMIN000015522. Written informed consent was obtained from all patients. Patients were category I (normal healthy patients, no organic, physiological, or psychiatric disturbances) or II (patients with mild systemic disease, no functional limitations) of the American Society of Anesthesiologists physical status classification [13]. Patients were randomly allocated to the GI and control groups using computer software that generated random whole numbers, where odd numbers were assigned to the control group and even numbers to the GI group. Patients who had diabetes mellitus, who were not able to continue GI infusion due to hypoglycemia, or whose actual operation time was less than $8 \mathrm{~h}$, were excluded from the analysis.

Anesthesia was induced by propofol $(2 \mathrm{mg} / \mathrm{kg})$ or thiopental sodium $(5 \mathrm{mg} / \mathrm{kg})$ and inhalation of sevoflurane with $66 \%$ nitrous oxide in oxygen. Tracheal intubation was then facilitated by intravenous vecuronium $(0.1 \mathrm{mg} /$ $\mathrm{kg}$ ) or rocuronium $(1 \mathrm{mg} / \mathrm{kg})$. In some cases, tracheotomy was performed under local anesthesia and then general anesthesia was induced using the same anesthetics that were described above. Anesthesia was maintained by sevoflurane and nitrous oxide in oxygen combined with an opioid analgesic, remifentanil (0.05$0.3 \mu \mathrm{g} / \mathrm{kg} / \mathrm{min}$ ). Patients were ventilated to maintain an end-tidal concentration of carbon dioxide at 35$40 \mathrm{mmHg}$. Routine patient monitoring included noninvasive blood pressure, invasive blood pressure through the radial artery, electrocardiogram, pulse oximetry, and an inspired/expired anesthetic gas and carbon dioxide, which were included in a patient monitor SOLAR 8000 (GE Marquette Medical Systems). Adequate analgesia was achieved by remifentanil, keeping the blood pressure of around $100 \mathrm{mmHg}$ and heart rate of 80 beats/min; hypertension $>140 \mathrm{mmHg}$ and tachycardia $>100$ beats/ min were avoided. Blood transfusion was performed when the hemoglobin concentration was $<8.0 \mathrm{~g} / \mathrm{dL}$ or unstable systolic blood pressure was $<80 \mathrm{mmHg}$.

In the control group, combination of acetate Ringer's solution which contains $1 \%(W / V)$ glucose and lactate Ringer's solution, which contains no glucose, was infused. Regular insulin was subcutaneously applied each time when a blood glucose concentration of $\geq 180 \mathrm{mg} /$ $\mathrm{dL}$ occurred. In the GI group, 1-4 U/h of regular insulin was continuously applied with infusion of glucosecontaining acetate Ringer's solution (5-10 g glucose per $500 \mathrm{~mL}$ ) during surgery. In the GI group, blood glucose was adjusted within the target concentration of $80-120 \mathrm{mg} / \mathrm{dL}$. Measurement of blood glucose concentrations was performed every $30 \mathrm{~min}$ during the operation. When the infusion rate of insulin was changed, blood glucose concentrations were measured every $15 \mathrm{~min}$ to avoid hypoglycemia. Briefly, in most cases, insulin was infused at $1-3 \mathrm{U} / \mathrm{h}$ for maintaining target glucose concentrations when acetate Ringer's solution, in which $10 \mathrm{~g}$ glucose was contained, was infused at a constant speed (e.g., $250 \mathrm{~mL} / \mathrm{h}$ for $50 \mathrm{~kg}$ body weight) throughout surgery. A second venous route was used to provide additional fluid (containing no glucose) when volume load was required. In both groups, low-dose dopamine $(3 \mu \mathrm{g} / \mathrm{kg} / \mathrm{min})$ was simultaneously administered to maintain renal blood flow and to obtain constant urine output. Arterial blood samples were analyzed every $2-3 \mathrm{~h}$ to prevent hypokalemia. Potassium chloride was supplemented (approximately $20 \mathrm{mEq} / \mathrm{h}$ ) to achieve a target plasma concentration of $4-4.5 \mathrm{mEq} / \mathrm{L}$ when hypokalemia $(<3.5 \mathrm{mEq} / \mathrm{L})$ was observed.

Pre- and postoperative C-reactive protein (CRP), body temperature measured in the armpit, total protein (TP) and serum albumin concentration, days until discharge, and incidence of postoperative hypoalbuminemia and complications were compared. Postoperative complications, i.e., surgical site infection (SSI) including methicillin-resistant Staphylococcus aureus (MRSA), necrosis of a reconstructed flap, bacteremia, hypotension, or pneumonia, indicated those which required additional therapeutic interventions. The highest body temperature was used when multiple measurements were performed within a day. Values of blood examinations at postoperative day 4 (Day4) or Day5 are represented as Day $4 / 5$, using the higher values of CRP and body temperature and the lower values of TP and serum albumin, when data at both days were available.

\section{Statistical analysis}

Data are expressed as means with standard deviation (SD). One-way analysis of variance was used to test significance between the two groups in the baseline numerical items, 
in the CRP concentration and body temperature for each time point, and days required until discharge. The chisquare test was used to test differences between the groups for baseline categorical items (sex, history of hypertension, dyslipidemia, and smoking habit), incidence of each postoperative complication, and number of patients who had postoperative complications. Correlations between the mean infusion rate of glucose applied during surgery $(X)$ and TP and serum albumin concentrations $(Y)$ were analyzed by Pearson's correlation coefficient, and relations were fitted by simple regression. Multiple linear regression analysis was performed to estimate the dependence of age, body mass index (BMI), mean infusion rate of glucose $(\mathrm{mg} / \mathrm{kg} / \mathrm{h})$ and insulin $(\mathrm{mU} / \mathrm{kg} / \mathrm{h})$ during surgery, operation time, total fluid volume, intraoperative blood loss, and intraoperative blood transfusion on the reduction of TP and albumin concentrations from the control to Day1 values. $P<0.05$ was considered statistically significant.

\section{Results}

The total number of patients enrolled in the study was 39. Nine patients were excluded from the data analysis due to short operation time less than $8 \mathrm{~h}$ (3 patients in the GI group), hypoglycemia during GI infusion (1 patient in the GI group), and diabetes mellitus (3 patients in the control group and 2 patients in the GI group). Thus, the total number of patients included in the data analysis was 30; the control group comprised 20 patients, and the GI group comprised 10 patients. Baseline patient characteristics are shown in Table 1. There were no differences in the clinical parameters between the two groups, except for the mean infusion rate of glucose and insulin during surgery.

Time course of the CRP concentration and body temperature are shown in Fig. 1. No significant difference was observed between the groups in the CRP concentration and body temperature. Regarding total protein and serum albumin concentrations, significant differences were observed at Day1 between the groups (Fig. 2a, b). Furthermore, significant correlations were observed between the mean infusion rate of glucose during surgery and TP at Day1 ( $R=0.63, P=0.0009$; Fig. $2 \mathrm{c})$ and serum albumin at Day1 ( $R=0.57, P=0.0009$; Fig. $2 \mathrm{~d})$, despite no significant relationships found before surgery.

The overall postoperative complications (they overlapped) and hypoalbuminemia in each group are shown in Table 2. Significant difference was observed between the two groups in the incidence of hypoalbuminemia $(P=0.0049)$. However, no significant difference was found in the incidence of hypotension, necrosis of a reconstructed flap, SSI, pneumonia or bacteremia, number of patients who had postoperative complications, and the days required until discharge.
Table 1 Baseline characteristics of the patients

\begin{tabular}{|c|c|c|c|}
\hline & $\begin{array}{l}\text { Control group } \\
(N=20)\end{array}$ & $\begin{array}{l}\text { Gl group } \\
(N=10)\end{array}$ & $P$ value \\
\hline Age (years) & $72.7 \pm 8.4$ & $77.0 \pm 8.2$ & 0.2010 \\
\hline $\operatorname{Sex}(M / F)$ & $12 / 8$ & $7 / 3$ & 0.5891 \\
\hline Weight (kg) & $52.0 \pm 8.0$ & $50.1 \pm 12.3$ & 0.6171 \\
\hline $\mathrm{BMI}\left(\mathrm{kg} / \mathrm{m}^{2}\right)$ & $21.4 \pm 2.5$ & $20.3 \pm 3.6$ & 0.3147 \\
\hline $\mathrm{SBP}(\mathrm{mmHg})$ & $132.6 \pm 21.9$ & $130.2 \pm 12.3$ & 0.7468 \\
\hline $\mathrm{DBP}(\mathrm{mmHg})$ & $70.0 \pm 9.7$ & $71.7 \pm 6.9$ & 0.6259 \\
\hline $\mathrm{HR}$ (/min) & $70.3 \pm 9.4$ & $71.0 \pm 6.1$ & 0.8453 \\
\hline Hypertension & $13(65.0 \%)$ & $4(40.0 \%)$ & 0.1928 \\
\hline Dyslipidemia & $6(30.0 \%)$ & $1(10.0 \%)$ & 0.1976 \\
\hline Current or past smoking & $9(45.0 \%)$ & $2(20.0 \%)$ & 0.1685 \\
\hline $\begin{array}{l}\text { Fasting plasma glucose } \\
(\mathrm{g} / \mathrm{dL})\end{array}$ & $90.2 \pm 10.4$ & $90.8 \pm 8.3$ & 0.8894 \\
\hline Triglyceride (mg/dL) & $111.5 \pm 56.7$ & $83.1 \pm 30.8$ & 0.1522 \\
\hline $\begin{array}{l}\text { Total cholesterol } \\
(\mathrm{mg} / \mathrm{dL})\end{array}$ & $188.4 \pm 32.8$ & $185.5 \pm 31.6$ & 0.8194 \\
\hline BUN (mg/dL) & $14.0 \pm 4.9$ & $16.9 \pm 4.0$ & 0.1266 \\
\hline $\begin{array}{l}\text { Serum creatinine } \\
(\mathrm{mg} / \mathrm{dL})\end{array}$ & $0.72 \pm 0.2$ & $0.70 \pm 0.1$ & 0.8518 \\
\hline eGFR (mL/min/1.73m²) & $79.7 \pm 15.5$ & $78.0 \pm 19.1$ & 0.8156 \\
\hline $\begin{array}{l}\text { Duration of operation } \\
\text { (min) }\end{array}$ & $744.3 \pm 168.3$ & $709.8 \pm 167.6$ & 0.6004 \\
\hline Duration of anesthesia & $903.3 \pm 158.4$ & $845.0 \pm 178.2$ & 0.3695 \\
\hline Total infusion (mL) & $4307 \pm 970$ & $3759 \pm 1284$ & 0.2015 \\
\hline Blood transfusion (mL) & $192.0 \pm 277.0$ & $280.0 \pm 329.3$ & 0.4474 \\
\hline $\begin{array}{l}\text { Intraoperative blood } \\
\text { loss }(\mathrm{mL})\end{array}$ & $470.3 \pm 285.4$ & $428.5 \pm 313.1$ & 0.7165 \\
\hline $\begin{array}{l}\text { Mean infusion rate of } \\
\text { glucose during surgery } \\
(\mathrm{mg} / \mathrm{kg} / \mathrm{h})\end{array}$ & $29.6 \pm 17.4$ & $68.0 \pm 14.8$ & $<0.0001^{*}$ \\
\hline $\begin{array}{l}\text { Mean infusion rate of } \\
\text { insulin during surgery } \\
(\mathrm{mU} / \mathrm{kg} / \mathrm{h})\end{array}$ & $0.2 \pm 1.2$ & $31.5 \pm 13.5$ & $<0.0001^{*}$ \\
\hline
\end{tabular}

Data are expressed as mean \pm SD

Gl glucose-insulin, $B M I$ body mass index, $S B P$ systolic blood pressure, $D B P$ diastolic blood pressure, $H R$ heart rate, $B U N$ blood urea nitrogen, eGFR estimated glomerular filtration rate

${ }^{*} P<0.05$ compared between the groups

Results of the multiple linear regression analysis are shown in Table 3. Mean infusion rate of glucose during surgery was independently associated with reduction of both TP and albumin concentrations from the control to Day1. Intraoperative blood transfusion was also associated with reduction of albumin.

\section{Discussion}

In the current study, we expected anti-inflammatory effects of tight glycemic control using GI infusion that have been demonstrated in heart surgery [10] and in critically ill patients [9]. However, the GI infusion did not affect CRP concentrations and body temperature. Instead, it 

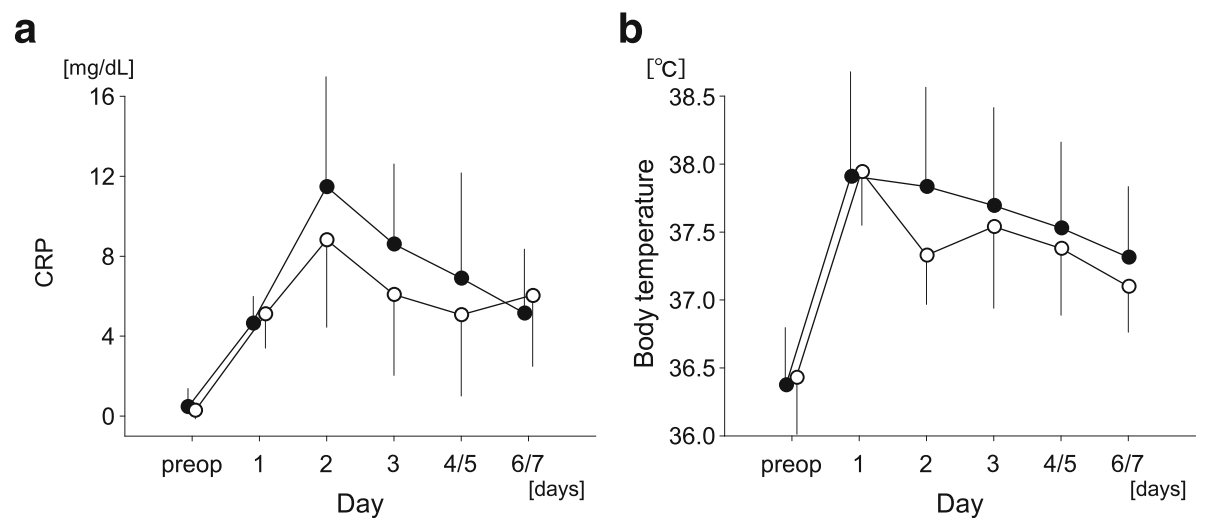

Fig. 1 Time course of CRP concentration (a) and body temperature (b) in the control group (closed circles) and the Gl group (open circles). Data are expressed as mean \pm SD. Day postoperative day, CRP C-reactive protein, Gl glucose-insulin. No significant difference was found between the groups

preserved higher TP and albumin concentrations than control subjects. Positive linear relationships were observed between the mean infusion rate of glucose during the surgery and both TP and albumin concentrations of Day1. Furthermore, the mean infusion rate of glucose during the surgery was an independent factor affecting the reduction in both TP and albumin concentration from the control to Day1. Therefore, it is additional glucose, but not insulin, that preserved TP and albumin concentrations.

It rarely induces hypoglycemia during surgery even if only lactate or acetate Ringer's solution that does not contain glucose is employed. However, it has been demonstrated that both breakdown of protein and fat

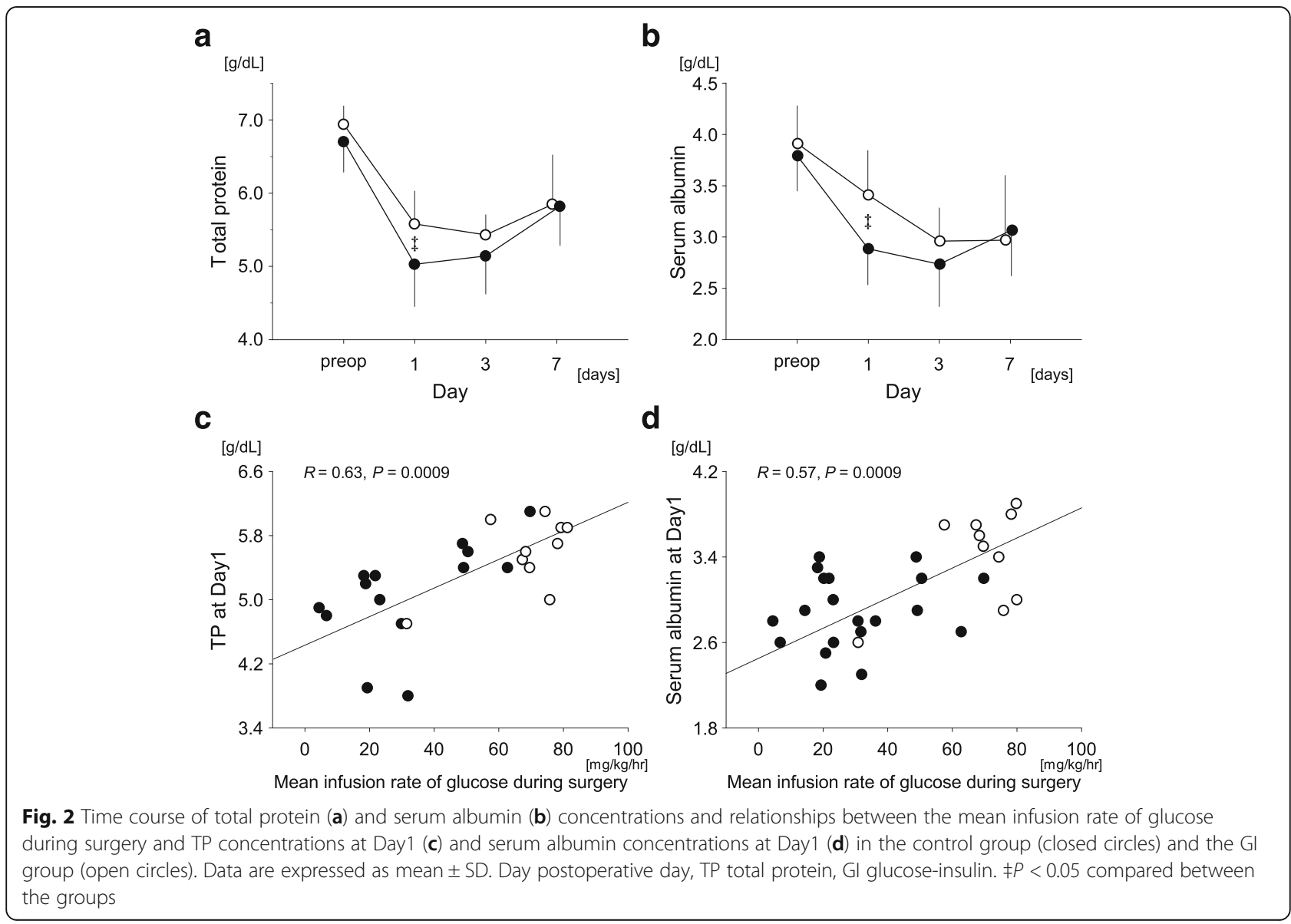


Table 2 Postoperative hypoalbuminemia and complications in each group

\begin{tabular}{|c|c|c|c|c|c|}
\hline & $\begin{array}{l}\text { Control group } \\
(N=20)\end{array}$ & & $\begin{array}{l}\text { Gl group } \\
(N=10)\end{array}$ & & $P$ value \\
\hline $\begin{array}{l}\text { Postoperative } \\
\text { hypoalbuminemia }\end{array}$ & 17 & & 4 & & $0.0122^{*}$ \\
\hline \multirow{5}{*}{$\begin{array}{l}\text { Postoperative } \\
\text { complications } \\
\text { (overlapping) }\end{array}$} & Hypotension & 6 & Hypotension & 1 & 0.1976 \\
\hline & $\begin{array}{l}\text { Necrosis of a } \\
\text { flap }\end{array}$ & 5 & $\begin{array}{l}\text { Necrosis of a } \\
\text { flap }\end{array}$ & 1 & 0.3104 \\
\hline & $\begin{array}{l}\text { SSI (including } \\
\text { MRSA) }\end{array}$ & 5 & $\begin{array}{l}\text { SSI (including } \\
\text { MRSA) }\end{array}$ & 1 & 0.3104 \\
\hline & Pneumonia & 1 & Pneumonia & 2 & 0.2122 \\
\hline & Bacteremia & 1 & Bacteremia & 0 & 0.3628 \\
\hline $\begin{array}{l}\text { Number of patients } \\
\text { who had postoperative } \\
\text { complications }\end{array}$ & 13 & & 4 & & 0.1928 \\
\hline Days until discharge & $85.6 \pm 44.4$ & & $68.8 \pm 22.5$ & & 0.2712 \\
\hline
\end{tabular}

Gl glucose-insulin, SSI surgical site infection, MRSA methicillin-resistant Staphylococcus aureus

${ }^{*} P<0.05$ between the groups

synthesis are reduced by using glucose-containing solution compared with normal saline solution during abdominal surgery [14], and that supplementation of a small dose of glucose in acetate Ringer's solution (1\% $W / V)$ during surgery inhibits breakdown of proteins [15]. Therefore, intraoperative energy requirements were compensated by breakdown of proteins and facilitated fat synthesis under the condition of decreased insulin

Table 3 Multiple linear regression analysis

\begin{tabular}{|c|c|c|c|}
\hline & & $\begin{array}{l}\text { Reduction of TP } \\
\text { from the control to } \\
\text { Day1 }\end{array}$ & $\begin{array}{l}\text { Reduction of albumin } \\
\text { from the control to } \\
\text { Day } 1\end{array}$ \\
\hline \multirow[t]{2}{*}{$\overline{\text { Age }}$} & $\beta$ & 0.0617 & -0.0001 \\
\hline & P & 0.7899 & 0.9995 \\
\hline \multirow[t]{2}{*}{$\mathrm{BMI}\left(\mathrm{kg} / \mathrm{m}^{2}\right)$} & $\beta$ & -0.3238 & -0.0474 \\
\hline & P & 0.1020 & 0.7838 \\
\hline \multirow[t]{2}{*}{ Operation time (min) } & $\beta$ & 0.2020 & 0.0190 \\
\hline & $P$ & 0.4621 & 0.9411 \\
\hline \multirow{2}{*}{$\begin{array}{l}\text { Total fluid volume } \\
(\mathrm{mL})\end{array}$} & $\beta$ & 0.4434 & 0.4326 \\
\hline & P & 0.2779 & 0.2886 \\
\hline \multirow{2}{*}{$\begin{array}{l}\text { Intraoperative blood } \\
\text { loss }(\mathrm{g})\end{array}$} & $\beta$ & 0.4543 & 0.1687 \\
\hline & $P$ & 0.0730 & 0.5044 \\
\hline \multirow{2}{*}{$\begin{array}{l}\text { Intraoperative blood } \\
\text { transfusion }(\mathrm{mL})\end{array}$} & $\beta$ & -0.4543 & -0.4872 \\
\hline & P & 0.0699 & $0.0307^{*}$ \\
\hline \multirow{2}{*}{$\begin{array}{l}\text { Mean infusion rate of } \\
\text { glucose during surgery } \\
(\mathrm{mg} / \mathrm{kg} / \mathrm{h})\end{array}$} & $\beta$ & -0.4279 & -0.5047 \\
\hline & $P$ & $0.0427^{*}$ & $0.0288^{*}$ \\
\hline \multirow{2}{*}{$\begin{array}{l}\text { Mean infusion rate of } \\
\text { insulin during surgery } \\
(\mathrm{mU} / \mathrm{kg} / \mathrm{h})\end{array}$} & $\beta$ & 0.0211 & 0.1764 \\
\hline & P & 0.9183 & 0.4462 \\
\hline
\end{tabular}

Italic typescript indicates statistical significance

TP total protein, Day 1 postoperative day $1, B M I$ body mass index, $\beta$

standardized partial regression coefficient secretion, when intraoperative fluid was solely managed with solutions that did not contain glucose.

It has been reported that continuous infusion of $0.25 \mu \mathrm{g} / \mathrm{kg} / \mathrm{h}$ remifentanil inhibited pneumoperitoneuminduced secretion of cortisol and ACTH but not that of catecholamines [16]. In the present study, we should have measured these hormones and compared them between the two groups to secure endocrine and adrenergic responses levels. Thus, we cannot exclude the possibility that remifentanil was not able to inhibit endocrine and/or adrenergic responses in this kind of surgery. In addition, low-dose dopamine, which is widely employed to increase renal blood flow in elderly patients, has been reported to induce insulin resistance [17]. It should be further noted that intraoperative insulin resistance was aggravated by low-dose dopamine.

The present study has limitations. First, we should have measured 3-methylhistidine, which is solely derived from catabolism of skeletal muscle [15], in order to observe direct evidence of protein sparing. Second, we should have measured several inflammatory cytokines, such as IL-6, IL-8, or TNF- $\alpha$, to clarify an association between GI infusion and inflammatory responses. Third, we should have employed solely lactate Ringer's solution which contains no glucose in the control group, because even a small dose of glucose administration during surgery can inhibit breakdown of proteins [15]. Instead, we have compared parameters between the two groups and performed multiple linear regression analysis by using mean infusion rate of glucose. Fourth, attention should be paid to evaluation of our results because of the relatively small number of patients enrolled. A larger scale study is required in the future to confirm the current findings.

\section{Conclusion}

Application of additional glucose during major oral and maxillofacial surgery preserved serum albumin concentration; however, it did not lead to less postoperative complications and less days until discharge.

\footnotetext{
Abbreviations

ACTH: Adrenocorticotropic hormone; BMI: Body mass index; BP: Blood pressure; CRP: C-reactive protein; Day: Postoperative day; Gl: Glucose-insulin; IL: Interleukin; MRSA: Methicillin-resistant Staphylococcus aureus; NADPH: Nicotinamide adenine dinucleotide phosphate; SSI: Surgical site infection; TNF: Tumor necrosis factor; TP: Total protein

Funding

This work was supported by a Grant-in-Aid for Scientific Research to Dr Tohya (no. 15 K20547) and Dr. Kohjitani (no. 16 K11756) from the Ministry of Education, Culture, Sports, Science and Technology of Japan.
}

\section{Authors' contributions}

AT and AK have made substantial contributions to conception and design. AT, SO, KY, and YM contributed to acquisition of data and analysis and interpretation of data. All authors have been involved in drafting the manuscript or revising it. All authors read and approved the final manuscript. 


\section{Ethics approval and consent to participate}

This study was conducted with approval from the Ethics Committee of Kagoshima University Medical and Dental Hospital (no. 297). This study was registered in the University Hospital Medical Information Network Clinical Trials Registry (UMIN-CTR), UMIN000015522. Written informed consent was obtained from all patients prior to participation.

\section{Competing interests}

The authors declare that they have no competing interests.

Received: 20 December 2017 Accepted: 10 January 2018

Published online: 22 January 2018

\section{References}

1. Akhtar S, Barash PG, Inzucchi SE. Scientific principles and clinical implications of perioperative glucose regulation and control. Anesth Analg. 2010;110:478-97.

2. Ljungqvist $O$, Nygren $J$, Thorell A. Insulin resistance and elective surgery. Surgery. 2000;128:757-60.

3. Iwasaka H, Itoh K, Miyakawa H, Kitano T, Taniguchi K, Honda N. Glucose intolerance during prolonged sevoflurane anaesthesia. Can J Anaesth. 1996; 43:1059-61.

4. Wood IS, Trayhurn P. Glucose transporters (GLUT and SGLT): expanded families of sugar transport proteins. Br J Nutr. 2003;89:3-9.

5. Wautier MP, Chappey O, Corda S, Stern DM, Schmidt AM, Wautier JL. Activation of NADPH oxidase by AGE links oxidant stress to altered gene expression via RAGE. Am J Physiol Endocrinol Metab. 2001;280:E685-94.

6. Wright E Jr, Scism-Bacon JL, Glass LC. Oxidative stress in type 2 diabetes: the role of fasting and postprandial glycaemia. Int J Clin Pract. 2006;60:308-14.

7. Basta G, Schmidt AM, De Caterina R. Advanced glycation end products and vascular inflammation: implications for accelerated atherosclerosis in diabetes. Cardiovasc Res. 2004;63:582-92.

8. Dandona P, Aljada A, Mohanty P, et al. Insulin inhibits intranuclear nuclear factor kappaB and stimulates IkappaB in mononuclear cells in obese subjects: evidence for an anti-inflammatory effect? J Clin Endocrinol Metab. 2001;86:3257-65.

9. van den Berghe $G$, Wouters $P$, Weekers $F$, et al. Intensive insulin therapy in critically ill patients. N Engl J Med. 2001;345:1359-67.

10. Lazar HL, Chipkin SR, Fitzgerald CA, Bao Y, Cabral H, Apstein CS. Tight glycemic control in diabetic coronary artery bypass graft patients improves perioperative outcomes and decreases recurrent ischemic events. Circulation. 2004;109:1497-502.

11. Furnary AP, Gao G, Grunkemeier GL, et al. Continuous insulin infusion reduces mortality in patients with diabetes undergoing coronary artery bypass grafting. J Thorac Cardiovasc Surg. 2003;125:1007-21.

12. Hasegawa A, Iwasaka $H$, Hagiwara $S$, et al. Anti-inflammatory effects of perioperative intensive insulin therapy during cardiac surgery with cardiopulmonary bypass. Surg Today. 2011:41:1385-90.

13. Keats AS. The ASA classification of physical status - a recapitulation. Anesthesiology. 1978:49:233-6.

14. Schricker T, Lattermann R, Carli F. Intraoperative protein sparing with glucose. J Appl Physiol (1985). 2005;99:898-901.

15. Yamasaki K, Inagaki Y, Mochida S, Funaki K, Takahashi S, Sakamoto S. Effect of intraoperative acetated Ringer's solution with $1 \%$ glucose on glucose and protein metabolism. J Anesth. 2010;24:426-31.

16. Watanabe K, Kashiwagi K, Kamiyama T, et al. High-dose remifentanil suppresses stress response associated with pneumoperitoneum during laparoscopic colectomy. J Anesth. 2014;28:334-40.

17. Ustione A, Piston DW, Harris PE. Minireview: dopaminergic regulation of insulin secretion from the pancreatic islet. Mol Endocrinol. 2013;27:1198-207.

\section{Submit your manuscript to a SpringerOpen ${ }^{\circ}$ journal and benefit from:}

- Convenient online submission

- Rigorous peer review

- Open access: articles freely available online

- High visibility within the field

- Retaining the copyright to your article

Submit your next manuscript at $\boldsymbol{\nabla}$ springeropen.com 